\title{
Exploring the value of peer feedback in online learning for the provider
}

Citation for published version (APA):

van Popta, E., Kral, M., Camp, G., Martens, R. L., \& Simons, P. R-J. (2017). Exploring the value of peer feedback in online learning for the provider. Educational Research Review, 20, 24-34.

https://doi.org/10.1016/j.edurev.2016.10.003

DOI:

10.1016/j.edurev.2016.10.003

Document status and date:

Published: 01/02/2017

Document Version:

Peer reviewed version

Document license:

CC BY-NC-ND

Please check the document version of this publication:

- A submitted manuscript is the version of the article upon submission and before peer-review. There can be important differences between the submitted version and the official published version of record. People interested in the research are advised to contact the author for the final version of the publication, or visit the DOI to the publisher's website.

- The final author version and the galley proof are versions of the publication after peer review.

- The final published version features the final layout of the paper including the volume, issue and page numbers.

Link to publication

\section{General rights}

Copyright and moral rights for the publications made accessible in the public portal are retained by the authors and/or other copyright owners and it is a condition of accessing publications that users recognise and abide by the legal requirements associated with these rights.

- Users may download and print one copy of any publication from the public portal for the purpose of private study or research.

- You may not further distribute the material or use it for any profit-making activity or commercial gain

- You may freely distribute the URL identifying the publication in the public portal.

If the publication is distributed under the terms of Article $25 f a$ of the Dutch Copyright Act, indicated by the "Taverne" license above, please follow below link for the End User Agreement:

https://www.ou.nl/taverne-agreement

Take down policy

If you believe that this document breaches copyright please contact us at:

pure-support@ou.nl

providing details and we will investigate your claim.

Downloaded from https://research.ou.nl/ on date: 26 Apr. 2023 


\section{Accepted Manuscript}

Exploring the Value of Peer Feedback in Online Learning for the Provider

Esther van Popta, Marijke Kral, Gino Camp, Rob L. Martens, P. Robert-Jan Simons

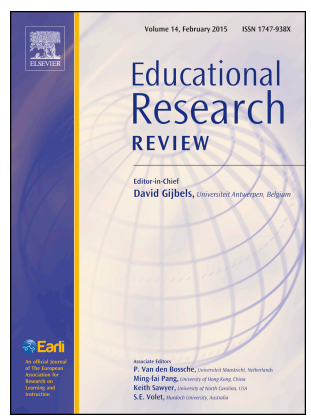

PII: $\quad$ S1747-938X(16)30056-2

DOI: $\quad$ 10.1016/j.edurev.2016.10.003

Reference: EDUREV 204

To appear in: Educational Research Review

Received Date: 6 January 2015

Revised Date: 10 October 2016

Accepted Date: 20 October 2016

Please cite this article as: van Popta, E., Kral, M., Camp, G., Martens, R.L., Simons, P.R.-J., Exploring the Value of Peer Feedback in Online Learning for the Provider, Educational Research Review (2016), doi: 10.1016/j.edurev.2016.10.003.

This is a PDF file of an unedited manuscript that has been accepted for publication. As a service to our customers we are providing this early version of the manuscript. The manuscript will undergo copyediting, typesetting, and review of the resulting proof before it is published in its final form. Please note that during the production process errors may be discovered which could affect the content, and all legal disclaimers that apply to the journal pertain. 
Running head: EXPLORING VALUE PEER FEEDBACK IN ONLINE LEARNING

Exploring the Value of Peer Feedback in Online Learning for the Provider

Esther van Popta and Marijke Kral

HAN University of Applied Sciences, Arnhem/Nijmegen, The Netherlands

Gino Camp and Rob L. Martens

Open University of the Netherlands, Heerlen, The Netherlands

P. Robert-Jan Simons

Visie op leren, Amsterdam, The Netherlands

Correspondence concerning this article should be addressed to Esther van Popta, HAN University of Applied Sciences, Service Unit O\&O, Postbus 5375, 6802 EJ Arnhem. Email: esther.vanpopta@han.nl 


\section{Abstract}

This paper reviews studies of peer feedback from the novel perspective of the providers of that feedback. The possible learning benefits of providing peer feedback in online learning have not been extensively studied. The goal of this study was therefore to explore the process of providing online peer feedback as a learning activity for the provider. We concluded that (1) providing online peer feedback has several potential learning benefits for the provider; (2) when providing online peer feedback, students use different cognitive processes; (3) the cognitive processes and the potential learning benefits can be realised when students use specific elements in the feedback they provide.

Research highlights

- We explore providing online peer feedback as a learning activity.

- In providing online peer feedback, a student has different potential learning benefits.

- In providing online peer feedback, a student uses different cognitive processes.

- Learning from giving online peer feedback is related to the use of specific elements in the feedback.

- We present a process model for providing online peer feedback.

Keywords

Peer feedback; Online learning; Feedback quality; Providing peer feedback 


\section{Introduction}

It is generally agreed that feedback plays an important role in learning: Hattie and Timperley (2007), for example, conclude that feedback is one of the most powerful variables influencing learning. Feedback refers to all post-response information that informs learners about their actual state of learning or performance in order to regulate the further process of learning in the direction of the learning standards strived for (Narciss, 2008, 2012; Shute, 2008). Feedback can be provided by various sources, one of which is the learner's peer, in which equal-status learners provide feedback. A paper by Liu and Carless (2006) draws on a large-scale survey of 1740 students and 400 academics, and they argue that the process of peer feedback engages students actively in learning, helps develop self-management and judgement, strengthens the capacity for self-assessment, helps develop subject knowledge, enables students to receive feedback faster and promotes social interaction. They argue that learning to provide peer feedback may even prepare students for life beyond higher education as it helps to develop their capacity to evaluate the quality and impact of their own work and the work produced by others. Giving peer feedback is a reciprocal process whereby students produce written or oral feedback on the work of peers and receive feedback from peers on their own work, and it can be regarded as both a form of peer assessment (Topping, 1998) and a form of peer review. Existing research shows a strong focus on arranging peer feedback as part of peer assessment (e.g. Tseng \& Tsai, 2007). The study by Liu and Carless (2006) reports on a large-scale survey of staff and students in Hong Kong, showing lack of interest in, and even resistance to, providing peer feedback as part of grading. Instead of using peer feedback as part of peer assessment, they propose using peer feedback processes as ends in themselves. Nicol and Macfarlane-Dick (2006) come to the same conclusion. In their paper on formative assessment and self-regulated learning, they suggest reinterpreting the research on formative assessment and feedback in order to use these processes to help students take 
control of their own learning. Along the same lines, Nicol (2013) proposes implementing peer review instead of peer assessment, in which peer review is an arrangement whereby students evaluate and provide feedback on the work of peers and, in turn, receive feedback from peers on their own work.

In recent years, the process of providing peer feedback has been increasingly facilitated online. Asynchronous and written peer feedback is the most widespread instance of online peer feedback. Some authors argue that peer feedback may play an even more important role in online learning (Lynch, 2002; Palloff \& Pratt, 2001) than in traditional face-to-face learning. Feedback is important for students to stay connected in online courses. Due to a lack of feedback, they are more likely to disconnect than students in face-to-face courses (Ko \& Rossen, 2001). Lack of feedback is most often cited as the reason for withdrawing from online courses (Ertmer et al., 2007). Ko and Rossen (2001) found that the online activity of students is stimulated by feedback. To attain a high level of feedback in online learning, however, instructors would have to be online almost continuously (Dunlap, 2005). The physical distance between teacher and students makes it difficult to facilitate discourse between the participants. The introduction of peer feedback in online learning can help to realise the required feedback so as to improve the quality of the discourse (Ertmer et al., 2007), and subsequently the quality of learning. Corgan, Hammer, Margolies, and Crossley (2004) conclude that the use of peer feedback in online learning enhances community building. By providing feedback on the work of their peers, students participate in each other's learning and thus achieve greater understanding and appreciation for their peers' experiences and perspectives.

As peer feedback is a two-way process, it is remarkable that most studies on peer feedback in online learning (e.g., Guardado \& Shi, 2007; Smits, Boon, Sluijsmans, \& Van Gog, 2008) only focus on the influence of peer feedback on the performance of the receiver 
and not on the possible learning benefits for the provider. A few studies have suggested that there might be differences in learning effects between receiving and providing written peer feedback in online learning. For instance, Van der Pol, Van den Berg, Admiraal and Simons (2008) conclude that the learning effects of providing online peer feedback can be felt as long as students invest time and effort into actively constructing content-oriented responses.

Narciss (2013) suggests that working in digital, collaborative learning environments requires empirical research on the effects of peer feedback on both the feedback provider and the feedback receiver. Other authors explore the benefits of providing more in-depth feedback. Liu, Lin, Chiu, and Yuan (2001) conclude from their study of the effects of using a feedback format in an online peer assessment that providing online written peer feedback requires students to read, compare, or question ideas; suggest modifications; and even reflect on how well one's own work compares with others.

Many studies on peer feedback appear to be based on the value of peer feedback for the receiver and on arranging peer feedback as part of peer assessment. Although both views are important, this overemphasis on the added value for the receiver and on peer assessment might lead to a limited understanding of peer feedback as a two-way process and of the added value of peer feedback for the provider. The goal of this article is thus to contribute to the existing body of knowledge about peer feedback by further exploring the perspective of the providers of online peer feedback. We will explore providing online peer feedback as a learning activity in higher education. First, we will explore which benefits for the provider can be found in current research. As providing feedback to one's peers is known to be difficult for students (Dochy, Segers, \& Sluijsmans, 1999; Topping, Smith, Swanson, \& Elliot, 2000), these benefits are not guaranteed. Next, we will explore the process of providing peer feedback, focusing on the cognitive processes such as critical thinking 
involved in providing this feedback. Finally, we will explore current literature for factors that are related to this process. The goal of this study is to answer the following questions:

1. What are the learning benefits for students who provide online peer feedback?

2. Which cognitive processes does a student use in providing online peer feedback?

3. What factors (student and context) are related to the process of providing online peer feedback?

\section{Method}

\subsection{Approach}

In order to find the appropriate concepts for our search of the literature we first studied the review studies on feedback that were cited in most other articles on feedback. These were the meta-analysis by Kluger and DeNisi (1996, based on 131 articles), and the meta-analysis by Hattie and Timperley (2007, based on a synthesis of 500 meta-analyses). We studied the literature reviews by Sadler (1989, based on 49 articles), by Black and Wiliam (1998, based on 250 articles), and by Shute (2008, based on 103 articles, and 24 books and book chapters). Based on the analyses of these five reviews in relation to our research questions, we found the following key concepts as a basis for establishing keywords and search terms: providing online peer feedback, cognitive processes, learning benefits, and background and context factors.

\subsection{Search and review strategies}

Searches for relevant literature were conducted using the Educational Resources Information Center (ERIC), Google Scholar, Scopus, and Web of Science. These online databases were searched for the years 1990 to 2015. All searches were limited to research published in English.

Key criteria were used in the decision tree for selecting articles to include or exclude in the literature review. We located each document and reviewed the abstract—or entire 
document if there was no abstract—-to determine if the document met our inclusion criteria.

We included studies that discussed online peer feedback from the perspective of the provider and studies that reviewed one or more of the following aspects related to providing online peer feedback: the cognitive processes involved, background and context factors, and any learning benefits resulting from the feedback. We excluded papers that did not focus on higher education and documents that were published before 1990.

Once abstracts had been identified as relevant to the criteria and worthy of further exploration, the full article was accessed. The articles were scanned, after which a further selection was made based on criteria including the terms discussed above.

\section{Results}

In this article, we explored providing online peer feedback as a learning activity. This exploration started with the search for relevant research in this area, and the results of this search can be found in the next section. These results were used to examine the benefits for the provider, the cognitive processes, and the specific factors that are related to the process of providing online peer feedback.

\subsection{Overview of relevant research}

The resulting literature included only 8 peer-reviewed journal articles. Among the included studies, all focused on providing online peer feedback and the perspective of the provider; 1 was a literature review and 7 were empirical studies (Table 1). Each document was critically reviewed and analyzed to determine the cognitive processes involved in providing online peer feedback, the possible learning benefits, and the requirements for learning. In our search, we found some relevant studies on providing peer feedback without a specific online context. This resulted in an additional set of 6 studies related to providing peer feedback as a learning activity (Table 2). 
TABLE 1

Studies related to providing online peer feedback as a learning activity for the provider

\begin{tabular}{lll}
\hline Study & Study description & Method \\
\hline Davies and & Study of a project that uses & Empirical research \\
Berrow & computer-supported peer & with part-time students \\
(1998) & review to develop higher- & from a MSc course in \\
& level learning skills and & Computer \\
& evaluation of the & Studies (N=16). \\
effectiveness. &
\end{tabular}

Major findings in relation to the research question

Learning benefits

improve their higher-level learning skills.

Cognitive processes

Background and context factors

Interviews with the subjects did not reveal any relation between positive attitudes to the effectiveness of the

approach in developing higher-level

learning skills and any of the following

measures: anticipatory anxiety, academic

locus of control, and final module grade.

The results of applying KAI (a post hoc administration of Kirton's

hoc administration of Kirton's
Adaptation-Innovation Inventory)

showed that subjects who scored higher

on aspects of risk, challenge, and

adaptability were more likely to feel that

the approach helped to improve their

Ertmer et al. This study investigates the impact of peer feedback

Empirical research with graduate student enrolled in an online used as an instructional strategy to increase the quality of students' online

In this study, most of the students described how they benefited from providing peer feedback.

Through this process, they reflected more critically

on the discussion postings for which they were providing feedback, as well as on their own

postings and how they could be improved in a similar manner.

Participants viewed peer review as effective and thought that they benefited from using this learning strategy. Students reported that the benefit of peer review came from reading many peers' works and obtaining critical insight from others' work during the review process. Many students mentioned that they compared their own work with peers' work and were more aware of their advantages and weaknesses than in situations with conventional teacher evaluation.
In reviewing peers' work, the student reads, compares, or questions ideas; suggests modification; or even reflects o how good one's own work is compared with others.

The qualitative analysis of metacognition showed that $77 \%$ of reviewers displayed all four kinds of higher-level thinking: planning, monitoring, regulation, and critical thinking. However, critical thinking and monitoring were more

frequently used than planning and regulation. students connect new concepts to
In providing online peer feedback,
In reviewing peers' work, a student starts by planning and completing his own assignment. 


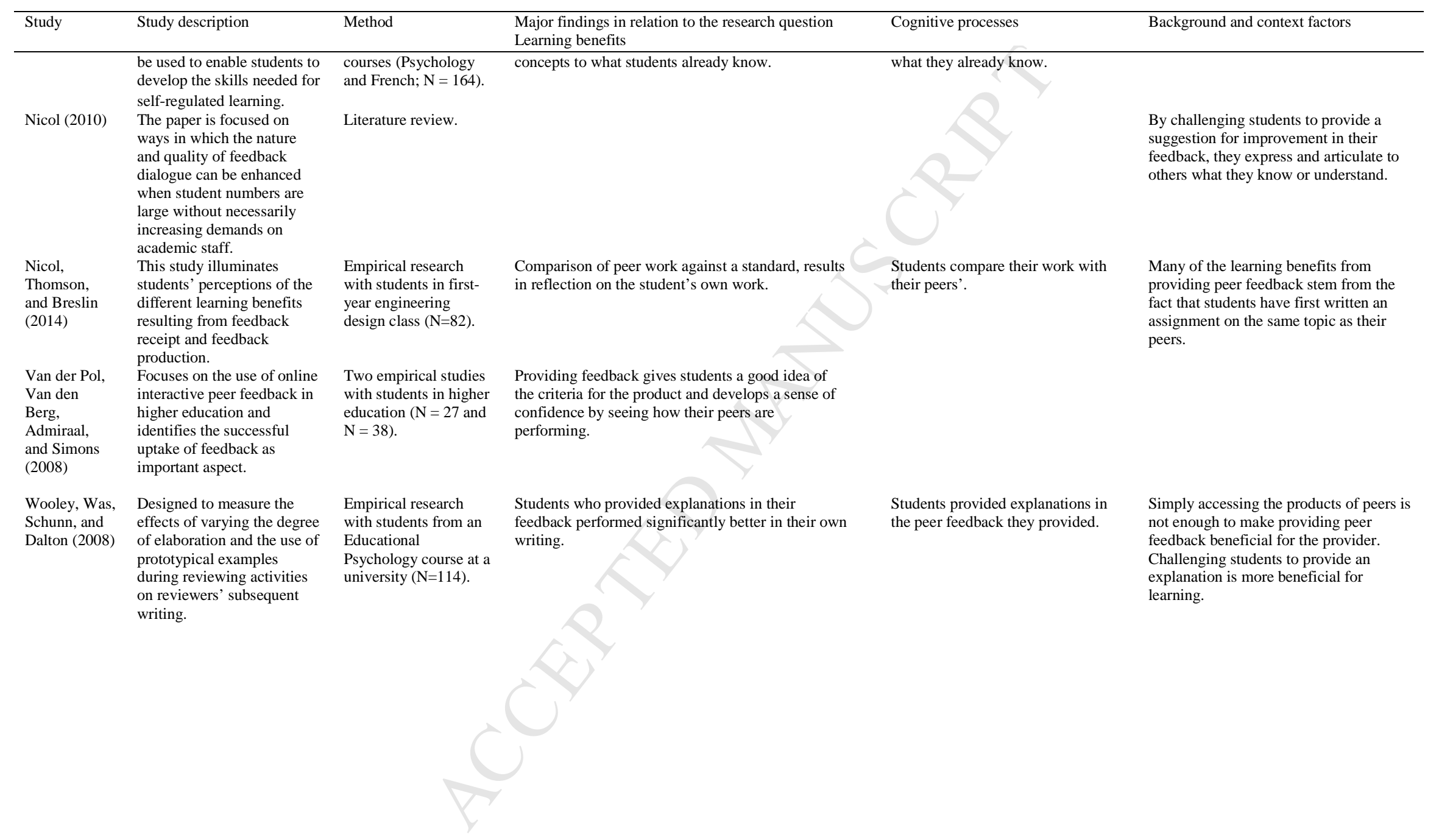


TABLE 2

Studies related to providing peer feedback as a learning activity for the provider in an offline setting

\begin{tabular}{|c|c|c|c|c|c|}
\hline Study & Study description & Method & $\begin{array}{l}\text { Major findings in relation to the research question } \\
\text { Learning benefits }\end{array}$ & Cognitive processes & Background and context factors \\
\hline $\begin{array}{l}\text { Boud and } \\
\text { Molloy (2013) }\end{array}$ & $\begin{array}{l}\text { Study on the development and analysis } \\
\text { of two models of feedback: teacher } \\
\text { feedback vs peer feedback. }\end{array}$ & $\begin{array}{l}\text { Literature } \\
\text { review. }\end{array}$ & $\begin{array}{l}\text { By providing feedback to peers, students develop } \\
\text { a capacity to make evaluative judgements about } \\
\text { their own work and that of others. }\end{array}$ & & \\
\hline $\begin{array}{l}\text { Dunlap and } \\
\text { Grabinger } \\
(2003)\end{array}$ & $\begin{array}{l}\text { Study on teaching methodologies for } \\
\text { lifelong learning. }\end{array}$ & $\begin{array}{l}\text { Literature } \\
\text { review. }\end{array}$ & $\begin{array}{l}\text { The process of reviewing someone else's work } \\
\text { can help learners reflect on and articulate their } \\
\text { own views and ideas, ultimately improving their } \\
\text { own work. }\end{array}$ & & \\
\hline $\begin{array}{l}\text { Liu and } \\
\text { Carless (2006) }\end{array}$ & $\begin{array}{l}\text { Study on peer feedback in relation to } \\
\text { assessment processes. It examines the } \\
\text { rationale for peer feedback, emphasising } \\
\text { its potential for enhanced student } \\
\text { learning. }\end{array}$ & $\begin{array}{l}\text { Empirical } \\
\text { research } \\
\text { on } 1740 \\
\text { students } \\
\text { and } 400 \\
\text { academics }\end{array}$ & $\begin{array}{l}\text { The process of peer feedback engages students } \\
\text { actively in learning, helps develop self- } \\
\text { management and judgement, strengthens the } \\
\text { capacity for self-assessment, and helps develop } \\
\text { subject knowledge. }\end{array}$ & & \\
\hline $\begin{array}{l}\text { Nicol and } \\
\text { Macfarlane- } \\
\text { Dick (2006) }\end{array}$ & $\begin{array}{l}\text { Review of current research of formative } \\
\text { assessment and feedback on how these } \\
\text { can help students take control of their } \\
\text { own learning. }\end{array}$ & $\begin{array}{l}\text { Literature } \\
\text { review. }\end{array}$ & $\begin{array}{l}\text { Providing peer feedback enables students to better } \\
\text { monitor, evaluate, and even regulate their own } \\
\text { learning independently of the teacher. }\end{array}$ & & \\
\hline Nicol (2012) & $\begin{array}{l}\text { Study on how to enhance students skills } \\
\text { on feedback from the assumption that } \\
\text { the purpose of feedback in HE is to } \\
\text { develop the students' capacity to make } \\
\text { evaluative judgements both about their } \\
\text { own work and that of others. }\end{array}$ & $\begin{array}{l}\text { Literature } \\
\text { review. }\end{array}$ & $\begin{array}{l}\text { The result of providing peer feedback is that the } \\
\text { students' own knowledge and understanding is } \\
\text { enhanced as a by-product of the production of } \\
\text { explanations in the feedback. } \\
\text { Reviewing the work of peers results in students } \\
\text { actively engaging in multiple evaluative acts and } \\
\text { in generating their own internal feedback: } \\
\text { feedback that is directly used to build new } \\
\text { knowledge and understanding, and that is directly } \\
\text { acted on. } \\
\text { In providing peer feedback, the students' own } \\
\text { ideas about the subject domain become available } \\
\text { for self-evaluation and updating. Students are not } \\
\text { only explaining a text they have read, they are } \\
\text { also evaluating it against criteria to produce } \\
\text { feedback justification. }\end{array}$ & $\begin{array}{l}\text { For feedback to foster evaluative } \\
\text { judgement, two cognitive processes are } \\
\text { exercised and developed: evaluation and } \\
\text { knowledge building. Representing both } \\
\text { (mental) processes is called 'reflective } \\
\text { knowledge building'. } \\
\text { In the feedback process, students reflect } \\
\text { on their own understanding and on their } \\
\text { own work as they construct explanations } \\
\text { for their peers. } \\
\text { When students are required to produce } \\
\text { explanations of conceptual ideas for peers, } \\
\text { they actively monitor, evaluate, and } \\
\text { rehearse their own understanding. } \\
\text { Reviewing the work of peers evokes } \\
\text { mental processes (monitoring, evaluating, } \\
\text { and rehearsing own understanding). It } \\
\text { requires that students evaluate texts } \\
\text { produced by peers to identify errors, gaps } \\
\text { in understanding, misconceptions, and }\end{array}$ & $\begin{array}{l}\text { Students must produce work in } \\
\text { the same domain themselves } \\
\text { before they can review the work } \\
\text { of their peers. }\end{array}$ \\
\hline
\end{tabular}




\begin{tabular}{|c|c|c|c|c|c|}
\hline Study & Study description & Method & $\begin{array}{l}\text { Major findings in relation to the research question } \\
\text { Learning benefits }\end{array}$ & Cognitive processes & Background and context factors \\
\hline & & & & $\begin{array}{l}\text { alternative viewpoints in those texts, and } \\
\text { that they also construct written feedback } \\
\text { commentaries. } \\
\text { When students are asked to make } \\
\text { judgements about the work of peers, they } \\
\text { start the reviewing process by comparing } \\
\text { the peer work against an internal } \\
\text { representation of their own work. Their } \\
\text { own work is the standard or benchmark } \\
\text { for any comparison. } \\
\text { When reviewing, students not only } \\
\text { compare their own work with that of } \\
\text { peers, but also they will compare and } \\
\text { evaluate the work of one peer against that } \\
\text { of another. }\end{array}$ & \\
\hline Nicol (2014) & $\begin{array}{l}\text { Study on peer review in relation to } \\
\text { development of evaluative skills and the } \\
\text { elaboration of knowledge. }\end{array}$ & $\begin{array}{l}\text { Literature } \\
\text { review. }\end{array}$ & $\begin{array}{l}\text { Depending on the depth of the mental processing, } \\
\text { this new conceptual knowledge will be } \\
\text { incorporated into existing knowledge networks } \\
\text { and will become personal capital that can be used } \\
\text { by students and adapted and applied to new } \\
\text { learning contexts. The act of evaluative } \\
\text { judgements is a 'knowledge-building' process. } \\
\text { Peer review is a suitable educational method for } \\
\text { developing students' skills in making evaluative } \\
\text { judgements. }\end{array}$ & $\begin{array}{l}\text { When students make judgements, they } \\
\text { interact with subject content, process it, } \\
\text { think about it, compare it with alternative } \\
\text { content, take different perspectives on it, } \\
\text { and create new knowledge that was not } \\
\text { contained in the material being judged. }\end{array}$ & $\begin{array}{l}\text { To fully realise the benefits of } \\
\text { peer review, students must } \\
\text { produce a written explanation for } \\
\text { their evaluative judgements. }\end{array}$ \\
\hline
\end{tabular}




\subsection{Learning benefits of providing online peer feedback}

In this article, the value of providing online peer feedback is explored. We explicitly focus on the benefits for the provider. As expected, the research in this field is scarce. In our search we found 5 relevant studies (see Table 1) with different learning benefits in an online context and 6 studies in a more general context (see Table 2).

One of the benefits for the provider of providing online peer feedback is the possibility of developing higher-level learning skills. A case study by Davies and Berrow (1998) showed that providing online peer feedback helped students to improve their higher-level learning skills of analysis and evaluation, but the responses of students showed different benefits. Nicol and Macfarlane-Dick (2006) argue that providing peer feedback should serve the function of enabling students to better monitor, evaluate, and even regulate their own learning independently of the teacher. As Van der Pol et al. (2008) argue, providing feedback gives students a good idea of the criteria for the product and develops a sense of confidence by seeing how their peers are performing.

Providing peer feedback gives students more critical insight and activates processes of reflection. In a small-scale research by Ertmer et al. (2007), students argued that the process of providing online peer feedback made them reflect more critically on the products of their peers and on their own work. These results are supported by the study of Liu et al. (2001) in which students reported profiting from providing online peer feedback. The benefit came from reading many peers' work and obtaining critical insight from others' work during the feedback process. Students mentioned that they compared their own work with peers' work and were more aware of their advantages and weaknesses than when in situations with conventional teacher evaluation. Nicol, Thomson, and Breslin (2014) found that comparison of peer work against a standard results in reflection on the student's own work. Dunlap and 
Grabinger (2003) argue that the process of reviewing someone else's work can help learners reflect on and articulate their own views and ideas.

Reflecting on the products of peers and on their own work is beneficial for the work of the providers in improving their own work (Dunlap \& Grabinger, 2003). Wooley, Was, Schunn, and Dalton (2008) found that students who provided explanations in their feedback performed significantly better in their own writing. Ertmer et al. (2007) found that the process of providing online peer feedback helped students to reflect more critically on how their own work could be improved.

Research by Nicol (2009) shows that providing online peer feedback involves meaning making and knowledge building. In providing feedback, students connect new concepts to what they already know. In his more recent research, Nicol (2012) argues that in the feedback process students construct explanations for their peers (reflective knowledge building) and as a result the students' own knowledge and understanding is enhanced as a by-product of the production of these explanations. In his latest research, Nicol (2014) concludes that, depending on the depth of the mental processing, the new conceptual knowledge will be incorporated into existing knowledge networks and will become personal capital that can be used by students and adapted and applied to new learning contexts. The act of providing evaluative judgements as part of peer feedback is a 'knowledge-building' process.

Providing peer feedback is a method for developing students' skills in making evaluative judgements (Liu et al., 2006; Nicol, 2014). Boud and Molloy (2013) confirm this benefit in their study on models of feedback. By providing feedback to peers, students develop a capacity to make evaluative judgements about their own work and that of others.

Taken together, the results of our research show that providing peer feedback can be beneficial for the provider, but research in this field is scarce. We found that it can help students to improve their higher-level learning skills, and it helps student to evaluate, 
monitor, and regulate their own learning. Students learn to reflect, become more critical, and may even improve their own product. Providing peer feedback can lead to more knowledge, and it can help students to make better evaluative judgements. Most of the benefits we found in our research were related to higher-level cognition or metacognition. It seems that providing peer feedback has a positive effect on students' metacognitive skills. In the next section, we will focus on the process of providing peer feedback and more explicitly on the cognitive processes student use in providing this feedback.

\subsection{Cognitive processes involved in providing online peer feedback}

Little research has been done on the cognitive processes involved in peer feedback from the providers' perspective. In the context of providing peer feedback in an online environment, only 4 articles were found, each with different results (see Table 1). 2 studies were found on the cognitive processes involved in providing peer feedback in a more general context (see Table 2).

In their study on implementing a web-based peer review system, Liu et al. (2001) found that before providing online peer feedback students start by completing their own assignment. When providing peer feedback, students first read the learning product of their peers and try to understand the product. One on the first cognitive processes students use to provide online peer feedback is that they compare the product of their peer with their own product and question the ideas of their peers in relation to their own product. Students think of suggestions for how to improve the learning product and reflect on how well their own work has been done, compared to that of others. Liu et al. (2001) found that students use different cognitive processes in providing peer feedback: planning, monitoring, regulation, and critical thinking.

Nicol et al. (2014) conclude in their studies that students who provide peer feedback compare their own work with the work of their peers. Nicol $(2012,2014)$ has investigated 
providing peer feedback in an offline context. In these studies, he found that when students are asked to make judgements about the work of their peers, they start the reviewing process by comparing the peer work against an internal representation of their own work. Their own work is the standard or the benchmark for any comparison. When reviewing, students not only compare their own work with that of peers, but they will also compare and evaluate the work of one peer against that of another.

Nicol (2009) found that through reflection students connect new concepts to what they already know. Nicol $(2012,2014)$ calls the mental processes related to providing peer feedback reflective knowledge building. Reviewing the work of peers results in students actively engaging in multiple evaluative acts and in generating their own internal feedbackfeedback that is directly used to build new knowledge and understanding, and that is directly acted on.

Nicol $(2012,2014)$ distinguishes two elements in reflective knowledge building: providing an evaluative judgement and providing an explanation. When students provide judgements, they interact with the subject content, process it, think about it, compare it with alternative content, take different perspectives on it, and create new knowledge. The other element in reflective knowledge building that Nicol (2012) mentions is giving an explanation in the feedback. When students are asked to give an explanation, they actively have to use the following cognitive processes: monitoring, evaluating, and rehearsing their own understanding. Reviewing the work of peers evokes these mental processes. It requires students to evaluate the work of their peers to identify errors, gaps in understanding, misconceptions, and alternative viewpoints, and to construct written feedback. In doing so, the students' own ideas about the subject becomes available for self-evaluation and updating. Students are not only explaining a text they have read, they are evaluating it against criteria to 
produce feedback justification. Wooley et al. (2008) found that students give explanations in the feedback they provide to their peers.

In sum, we found that students use different cognitive processes when they are asked to provide online peer feedback. Students compare and question ideas; evaluate; suggest modifications; and reflect, plan, and regulate their own thinking. They think critically, connect to new knowledge, explain, and take different perspectives. The possible benefits and the cognitive processes are related. Using specific cognitive processes will help students to realise learning benefits. Together they shape the direction for designing the instruction for providing online peer feedback. In the next section, we will focus on the context and student factors that are related to the process of providing peer feedback.

\subsection{Context and student factors involved in providing online peer feedback}

The sections above provided insight into the benefits of providing peer feedback and the mental processes that are involved. The realisation of the benefits and the actual use of the cognitive processes are probably determined by context factors, including instruction materials and student factors such as previous education. Research on these factors in relation to the process of providing online peer feedback is rare. In our search, we found 4 relevant studies in an online context (see Table 1) and 2 studies in a more general context (see Table 2). Only one study was found on background factors; the other studies were explorative studies.

As argued above, students use cognitive processes to provide online peer feedback, which will lead to several benefits. This shapes the ideas on designing a process of providing peer feedback in a way that it is beneficial for the provider. Nicol (2010) found that students must be challenged to provide suggestions for improvement in the peer feedback they provide. Only then will they express and articulate to others what they know and understand. Wooley et al. (2008) argue that students must be challenged to provide explanations in their feedback. 
These explanatory activities are more beneficial for learning than simply reading the products of peers. Students who provided explanations in their feedback performed significantly better in their own writing. Nicol (2014) adds that to fully realise the benefits of peer review students must produce a written explanation for their evaluative judgements. Producing explanations is a constructive learning activity, requiring that reviewers generate and articulate ideas that go beyond the peer's text.

Nicol et al. (2014) found that aside from instructing students to provide suggestions and explanations, many of the learning benefits from providing online peer feedback stem from the fact that students have first written an assignment on the same topic as their peers. This is also the case from an offline perspective. Students must produce work in the same area themselves before they can review the work of their peers (Nicol, 2012).

The study by Davies and Berrow (1998) was the only research we found that showed relevant results on student factors. In their small study with part-time students from a Master of Science course in computer studies on the effectiveness of providing online peer feedback in developing higher-level learning skills, they found that students who scored higher on aspects of risk, challenge, and adaptability were more likely to feel that the approach helped to improve their higher-level learning skills.

The results presented here give us a perception of the possible benefits, the cognitive processes involved, and related context and student factors of providing online peer feedback. These results are used for the development of a process model of providing online peer feedback that is presented in the next section.

\subsection{Towards a process model of providing online peer feedback}

The results from the literature review endorse our argument that providing online peer feedback has potential learning benefits for the provider and requires students to use different 
cognitive processes under specific instructional circumstances. When providing online peer feedback, students review the work of their peers. Before they can review the work of their peers, they make a product based on the same assignment. By being challenged to provide specific elements in their peer feedback, they will use different cognitive processes. These elements are an evaluative judgement, a suggestion for improvement, and an explanation. In providing peer feedback, students interact with subject content, process, think, compare, take different perspectives, and create new knowledge. When giving an explanation, students monitor, evaluate, and rehearse their own understanding. Nicol $(2012,2014)$ use the term reflective knowledge building to describe these processes taken together. According to the framework of reflective thinking (Sparks-Langer, Simmons, Pasch, Colton, and Starko, 1990), adding an explanation to feedback shows a higher level of reflective thinking. The explanation can be justified by adding reference to ones' own knowledge. At an even higher level of reflective thinking, a student provides reference to relevant theoretical concepts to support the explanation. In the final step of the process, students write one or more peer feedback fragments and sends these to their peers. The students can use their new insights to improve their own product. On the one hand, students need certain competences to be able to do reflective knowledge building and provide online peer feedback. However, the act of providing online peer feedback is in itself a learning activity.

Figure 1 represents a process model for learning by providing online peer feedback from the perspective of the provider that synthesises current thinking on the possible learning benefits, the cognitive functions processed, and the elements for learning that are related to the process of providing online peer feedback. The model was developed to help understand how providing online peer feedback is a learning activity. 
[Insert Fig. 1 about here]

Figure 1: Process Model Providing Online Peer Feedback

\section{Discussion}

This article aimed to add to the body of knowledge on peer feedback in online learning by considering the perspective of the providers of peer feedback and discussing the learning potential of providing peer feedback. The significance of the results of the review is that it resulted in a process model for providing online peer feedback. The model provides the first step toward a better understanding of the process of providing peer feedback and its added value for the provider. It is, however, based on only a few empirical studies, and therefore the model must be studied more in depth before it can be used in practice.

Different learning benefits were found in a limited number of studies on learning from providing peer feedback. To fully realise the learning benefits from providing online peer feedback, further research is required. The research must preferably be focused on the effectiveness of providing online peer feedback for the provider. One of the research questions could be: Will students reflect on their own work, and will it show in revisions of their own work after providing online peer feedback?

The current model has a strong cognitive perspective. Since providing online peer feedback is part of a collaborative process between at least two peers within in a larger group of learners, a social perspective would be relevant for the learning benefits and conditions for learning. For example, the visibility of the feedback makes the feedback part of a social process between the learners (Van der Pol et al., 2008). It is expected that social processes are related to the cognitive functions and learning benefits of providing online peer feedback.

Results from the review suggest that students can learn from providing peer feedback but research on context and student factors involved seemed rare. In future studies, we must focus on the conditions necessary for students to learn to provide peer feedback. More 
research is needed to learn whether student factors are related to the process of providing online peer feedback. If the model would be used to support teachers and students in improving the quality of the peer feedback provided, we should expand our research to conditions for learning that are related to the instructional—and especially online—context.

Our study focused on providing peer feedback in an online environment, more specifically on online, written peer feedback. The findings and the developed model apply to giving online, written peer feedback. It can be argued that the model also applies to giving peer feedback in an offline environment. The findings and the model are more tied to the fact that the feedback is written then to the fact that it is a web-enhanced process. The cognitive processes that are required to evaluate, suggest, explain and ground are not bound to the online component of the environment. There are also differences between an online and an offline peer feedback process: online reading might be different from offline reading (although the online environment does not mean that students have to read the products online); online writing might lead to shorter feedback statements; online feedback (and the result of the cognitive processes) is (mostly) visible for other students and the teacher; the social environment may be different from a face to face or class situation. In our review, we did not find research addressing the specific affordances of the online environment for giving peer feedback, nor addressing differences with an offline situation. Further research is needed to find out if it makes a difference whether the feedback process takes place in an online, offline or blended environment and if the model can be expanded with contextual requirements.

The limitation of the present study is tied to the scope of the review. We focused on providing peer feedback in online learning and in higher education. This should be taken into account when considering the extent to which our results can be generalised. We consider that the results could be interesting for educational concepts that are based on blended 
learning and also in contexts of secondary education. Studies by Tseng and Tsai (2007) and

Gielen, Peeters, Dochy, Onghena, and Struyven (2010) show the benefits of (online) peer feedback in high school courses.

If organised online, the impact of the online component of the peer feedback process must not be underestimated. As well as being a challenge for students, online learning is still a challenge for most teachers, and this is not only because of the technology itself. Laurillard (2009) argues that to get the best from technology for education, we need to start with the requirements of education, in terms of both learner and teacher needs. The implementation of the new perspective must take these aspects into account.

As providing feedback to one's peers is known to be difficult for students (Dochy et al., 1999; Topping et al., 2000), providing peer feedback that leads to learning doesn't come naturally. But given the results noted in this article, it is worth investing the time and effort to implement it. 


\section{References}

Black, P., \& Wiliam, D. (1998). Assessment and classroom learning. Assessment in Education, 5(1), 7-74.

Boud, D., \& Molloy, E. (2013). Rethinking models of feedback for learning: The challenge of design. Assessment \& Evaluation in Higher Education, 38(6), 698-712.

Corgan, R., Hammer, V., Margolies, M., \& Crossley, C. (2004). Making your online course successful. Business Education Forum, 58(3), 51-53.

Davies, R., \& Berrow, T. (1998). An evaluation of the use of computer supported peer review for developing higher-level skills. Computers \& Education, 30(1), 111-115.

Dochy, F. J. R. C., Segers, M., \& Sluijsmans, D. (1999). The use of self-, peer and coassessment in higher education: A review. Studies in Higher education, 24(3), 331-350.

Dunlap, J. C. (2005). Workload reduction in online courses: Getting some shuteye. Performance Improvement, 44(5), 18-25.

Dunlap, J. C., \& Grabinger, S. (2003). Preparing students for lifelong learning: A review of instructional features and teaching methodologies. Performance Improvement Quarterly, $16(2), 6-25$.

Ertmer, P. A., Richardson, J. C., Belland, B., Camin, D., Connolly, P., Coulthard, G., ...

Mong, C. (2007). Using peer feedback to enhance the quality of student online postings: An exploratory study. Journal of Computer Mediated Communication, 12(2), 412-433.

Gielen, S., Peeters, E., Dochy, F., Onghena, P., \& Struyven, K. (2010). Improving the effectiveness of peer feedback for learning. Learning and Instruction, 20(4), 304-315.

Guardado, M., \& Shi, L. (2007). ESL students' experiences of online peer feedback. Computers and Composition, 24(4), 443-461.

Hattie, J., \& Timperley, H. (2007). The power of feedback. Review of Educational Research, $77(1), 81-112$. 
Kluger, A. N., \& DeNisi, A. (1996). The effects of feedback interventions on performance: A historical review, a meta-analysis, and a preliminary feedback intervention theory. Psychological Bulletin, 119(2), 254-284.

Ko, S., \& Rossen, S. (2001). Teaching online: A practical guide. Boston: Houghton Mifflin.

Laurillard, D. (2009). The pedagogical challenges to collaborative technologies. International Journal of Computer-Supported Collaborative Learning, 4(1), 5-20.

Liu, E. Z.-F., Lin, S. S., Chiu, C. H., \& Yuan, S. M. (2001). Web-based peer review: The learner as both adapter and reviewer. IEEE Transactions on Education, 44(3), 246-251.

Liu, N. F., \& Carless, D. (2006). Peer feedback: The learning element of peer assessment. Teaching in Higher Education, 11(3), 279-290.

Lynch, M. M. (2002). The online educator: A guide to creating the virtual classroom. New York: Routledge.

Narciss, S. (2008). Feedback strategies for interactive learning tasks. In J. M. Spector, M .D. Merrill, J. J. G. van Merrienboer, \& M. P. Driscoll (Eds.), Handbook of research on educational communications and technology (3rd ed., pp. 125-144). Mahwah, NJ: Lawrence Erlbaum.

Narciss, S. (2012). Feedback in instructional contexts. In N. Seel (Ed.), Encyclopedia of the learning sciences (Vol. 6, pp. 1285-1289). New York: Springer.

Narciss, S. (2013). Designing and evaluating tutoring feedback strategies for digital learning environments on the basis of the Interactive Tutoring Feedback Model. Digital Education Review, 23, 7-26. Retrieved from http://greav.ub.edu/der

Nicol, D. (2009). Assessment for learner self-regulation: Enhancing achievement in the first year using learning technologies. Assessment \& Evaluation in Higher Education, 34(3), $335-352$. 
Nicol, D. (2010). From monologue to dialogue: Improving written feedback processes in mass higher education. Assessment \& Evaluation in Higher Education, 35(5), 501-517.

Nicol, D. (2012). Resituating feedback from the reactive to the proactive. In D. Boud \& E. Molloy (Eds.), Feedback in higher and professional education: Understanding it and doing it well (pp. 34-49). London: Routledge.

Nicol, D (2013) Peer review: Putting feedback processes in students' hands. Perspectives on Pedagogy and Practice, 4(1), 111-123.

Nicol, D. (2014). Guiding principles of peer review: Unlocking learners' evaluative skills. In C. Kreber, C. Anderson, N. Entwistle, \& J. McArthur (Eds.), Advances and innovations in university assessment and feedback (pp. 195-258). Edinburgh: Edinburgh University Press.

Nicol, D., \& Macfarlane-Dick, D. (2006). Formative assessment and self-regulated learning: A model and seven principles of good feedback practice. Studies in Higher Education, 31(2), 199-218.

Nicol, D., Thomson, A., \& Breslin, C. (2014). Rethinking feedback practices in higher education: A peer review perspective. Assessment \& Evaluation in Higher Education, $39(1), 102-122$.

Palloff, R. M., \& Pratt, K. (2001). Lessons from the cyberspace classroom: The realities of online teaching. San Francisco: Jossey-Bass.

Sadler, D. R. (1989). Formative assessment and the design of instructional systems. Instructional science, 18(2), 119-144.

Shute, V. J. (2008). Focus on formative feedback. Review of educational research, 78(1), 153-189. 
Smits, M. H., Boon, J., Sluijsmans, D. M., \& Van Gog, T. (2008). Content and timing of feedback in a web-based learning environment: Effects on learning as a function of prior knowledge. Interactive Learning Environments, 16(2), 183-193.

Sparks-Langer, G. M., Simmons, J. M., Pasch, M., Colton, A., \& Starko, A. (1990).

Reflective pedagogical thinking: How can we promote it and measure it? Journal of Teacher Education, 41(5), 23-32.

Topping, K. (1998). Peer assessment between students in colleges and universities. Review of Educational Research, 68(3), 249-276.

Topping, K. J., Smith, E. F., Swanson, I., \& Elliot, A. (2000). Formative peer assessment of academic writing between postgraduate students. Assessment \& Evaluation in Higher Education, 25(2), 149-169.

Tseng, S. C., \& Tsai, C. C. (2007). On-line peer assessment and the role of the peer feedback: A study of high school computer course. Computers \& Education, 49(4), 1161-1174. van der Pol, J., van den Berg, B. A. M., Admiraal, W. F., \& Simons, P. R. J. (2008). The nature, reception, and use of online peer feedback in higher education. Computers \& Education, 51(4), 1804-1817.

Wooley, R., Was, C., Schunn, C. D., \& Dalton, D. (2008, July). The effects of feedback elaboration on the giver of feedback. Paper presented at the 30th Annual Meeting of the Cognitive Science Society, Washington, DC. 
Elements for learning

Write feedback that

contains: evaluative

judgment, suggestion for

improvement,

explanation and reference

to theory

- Make assignment on the same topic

\section{Cognitive processes}

Compare and question ideas, evaluate, sugges

modifications and reflect, plan and regulate

own thinking | think critical, connect to new

knowledge, explain and take different perspectives
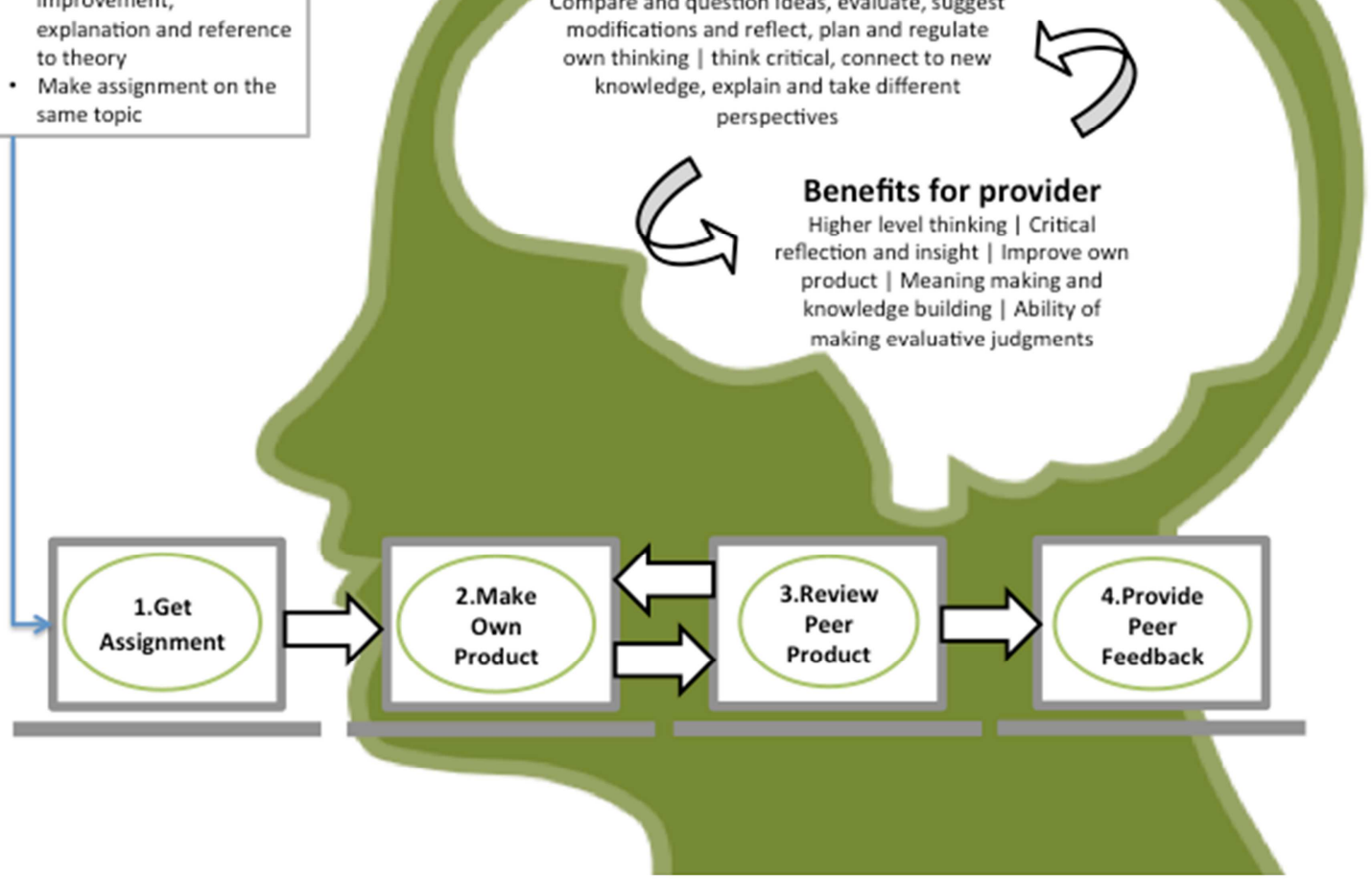

Process Model Providing Online Peer Feedback 